\title{
Light- and Melanin Nanoparticle-Induced Cytotoxicity in Metastatic Cancer Cells
}

\author{
Victoria R. Gabriele ${ }^{1,+}$, Robabeh M. Mazhabi ${ }^{2,+}$, Natalie Alexander ${ }^{3} \mathbb{D}$, Purna Mukherjee $^{3}$,

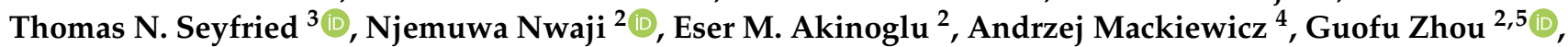 \\ Michael Giersig ${ }^{2,6}{ }^{D}$, Michael J. Naughton ${ }^{1}\left(\mathbb{D}\right.$ and Krzysztof Kempa ${ }^{1, *}$
}

Citation: Gabriele, V.R.; Mazhabi, R.M.; Alexander, N.; Mukherjee, P.; Seyfried, T.N.; Nwaji, N.; Akinoglu, E.M.; Mackiewicz, A.; Zhou, G.; Giersig, M.; et al. Light- and Melanin Nanoparticle-Induced Cytotoxicity in Metastatic Cancer Cells. Pharmaceutics 2021, 13, 965. https://doi.org/10.3390/ pharmaceutics 13070965

Academic Editor: Hassan Bousbaa

Received: 21 May 2021

Accepted: 23 June 2021

Published: 26 June 2021

Publisher's Note: MDPI stays neutral with regard to jurisdictional claims in published maps and institutional affiliations.

Copyright: (c) 2021 by the authors. Licensee MDPI, Basel, Switzerland. This article is an open access article distributed under the terms and conditions of the Creative Commons Attribution (CC BY) license (https:/ / creativecommons.org/licenses/by/ $4.0 /)$.
1 Department of Physics, Boston College, Chestnut Hill, MA 02467, USA; gabrievi@bc.edu (V.R.G.); naughton@bc.edu (M.J.N.)

2 International Academy of Optoelectronics at Zhaoqing, South China Normal University, Zhaoqing 526238, China; r.motaghed@zq-scnu.org (R.M.M.); njemuwa.nwaji@zq-scnu.org (N.N.); e.a@fu-berlin.de (E.M.A.); guofu.zhou@m.scnu.edu.cn (G.Z.); giersig@physik.fu-berlin.de (M.G.)

3 Department of Biology, Boston College, Chestnut Hill, MA 02467, USA; njalexander343@gmail.com (N.A.); purna.mukherjee@bc.edu (P.M.); thomas.seyfried@bc.edu (T.N.S.)

4 Greater Poland Cancer Centre, Poznan University of Medical Sciences, 61-867 Poznan, Poland; mackiewicz.aa@gmail.com

5 Guangdong Provincial Key Laboratory of Optical Information Materials and Technology \& Institute of Electronic Paper Displays, South China Academy of Advanced Optoelectronics, South China Normal University, Guangzhou 510006, China

6 Institute of Fundamental Technological Research of Polish Academy of Sciences, 02-106 Warsaw, Poland

* Correspondence: kris.kempa@bc.edu

$+\quad$ These authors contributed equally to this paper.

Abstract: Melanin nanoparticles are known to be biologically benign to human cells for a wide range of concentrations in a high glucose culture nutrition. Here, we show cytotoxic behavior at high nanoparticle and low glucose concentrations, as well as at low nanoparticle concentration under exposure to (nonionizing) visible radiation. To study these effects in detail, we developed highly monodispersed melanin nanoparticles (both uncoated and glucose-coated). In order to study the effect of significant cellular uptake of these nanoparticles, we employed three cancer cell lines: VM-M3, A375 (derived from melanoma), and HeLa, all known to exhibit strong macrophagic character, i.e., strong nanoparticle uptake through phagocytic ingestion. Our main observations are: (i) metastatic VM-M3 cancer cells massively ingest melanin nanoparticles (mNPs); (ii) the observed ingestion is enhanced by coating mNPs with glucose; (iii) after a certain level of mNP ingestion, the metastatic cancer cells studied here are observed to die-glucose coating appears to slow that process; (iv) cells that accumulate mNPs are much more susceptible to killing by laser illumination than cells that do not accumulate mNPs; and (v) non-metastatic VM-NM1 cancer cells also studied in this work do not ingest the mNPs, and remain unaffected after receiving identical optical energy levels and doses. Results of this study could lead to the development of a therapy for control of metastatic stages of cancer.

Keywords: melanoma; melanin nanoparticles; cytotoxicity; laser medical applications; hyperthermia

\section{Introduction}

The emergence of nanoparticle (NP) technology in biomedicine has led to many applications [1,2]. These include tumor imaging and targeting [3], tissue engineering [4], drug delivery [5], tumor destruction [6], pathogen detection [7], and protein detection [8], among others. Sufficiently small nonpolar NPs can cross biological barriers and translocate across cells, tissues, and organs [9]. In contrast, polar NPs can enter cells only by utilizing endocytotic pathways $[10,11]$. The internalization process of NPs by cells is a key factor in determining their biomedical function, toxicity, and biodistribution [11]. Adjusting chemophysical properties of NPs, such as size, shape, and surface properties, is a major factor for 
optimization of targeting and cellular uptake, as well as intracellular trafficking [12]. Zeta potential $(\xi)$ could be an important biophysical parameter for quantification of the cellular interactions [13-15].

Meanwhile, it has been also known for over a century that biomolecules can be irreversibly damaged by ionizing radiation, via photons with energy sufficient to break covalent bonds. For example, ultraviolet (UV) radiation is known to cause catastrophic damage to cells [16], and X-rays and even harder radiation have been long applied to treat cancer [17]. Such radiation damages of cells and tissue is largely indiscriminate, with minimal or no spectral control or biospecificity. Therefore, geometric targeting must be used to achieve some degree of macro-scale selectivity. Non-ionizing radiation, with photons of much lower energy can, at sufficient intensity, also cause irreversible damage to biomolecules via nonlinear processes (under high local electric or thermal field). Geometric targeting can be improved with such radiation due to the availability of lensing, in particular in the visible frequency range. Irreversible damage of geometrically microtargeted yeast cells was recently demonstrated, using laser tweezers employing a low power $(80 \mathrm{~mW})$, near infrared (NIR) laser focused to a spot of about $1 \mu \mathrm{m}$ diameter $\left(\sim 10^{10} \mathrm{~W} / \mathrm{m}^{2}\right)$ [18]. Most importantly, however, nonlinear effects produced by non-ionizing radiation allow for spectral resolution of the excitation. Spectra in the NIR and far IR (FIR) ranges consist typically of characteristic groups of absorbance maxima, which form so called "fingerprint" spectra, and which can be used to identify a given molecule [19]. A recent theoretical paper [20] suggested that such fingerprint spectra can be used to selectively damage target molecules within a cell. Such purely spectral selectivity of molecular dissociation would be highly desirable in future therapies, but it is currently very hard (or impossible) to achieve/implement, mainly because the spectra of different biomolecules (ranging from viral to cellular, healthy or cancerous) are very similar, typically with only some amplitude variations, but at similar or the same peak spectral locations (wavelengths) [21]. An additional complication is the generally small radiation penetration depth, apart from a few high transparency spectral windows [21,22].

These technical difficulties can be overcome with the incorporation of strongly lightabsorbing targets, such as NPs. For example, light absorption by melanin NPs is very strong (typically an order of magnitude more than typical cells) over a wide spectral range, a fact that has been exploited in the detection of metastatic melanoma circulating tumor cells (CTC) $[23,24]$. Several papers $[23,25]$ have shown that, for wavelengths around $500 \mathrm{~nm}$ and between $700 \mathrm{~nm}$ and $900 \mathrm{~nm}$, melanoma cells dominate absorption over that of blood, suggesting they may be able to be overheated with radiation at those wavelengths. In fact, melanin-filled NPs have been used recently to trigger cell death by overheating (over $42^{\circ} \mathrm{C}$ ) in tumors [26]. In such tumor therapy, radiation in the NIR high transparency window ( $~ 800 \mathrm{~nm}$ wavelength) is typically used.

We have developed highly monodispersed glucose-coated melanin nanoparticles (mNP@G), and have used these to reveal massive NP uptake by the three cancer cell lines, VM-M3, A375, and HeLa, which confirm these cell types' macrophagic character. Zeta potential measurements suggest that this character is related to binding and cellular internalization effects. Importantly, we find that the viability of all studied cells dramatically decreases at a sufficiently high concentration of mNP@G and reduction of the glucose level in the culture nutrition. We also performed a series of radiation experiments on cancer cells moderately filled with mNP@G. We employed light in the visible transmission window of blood at $532 \mathrm{~nm}$ wavelength [22,23], and demonstrated that there exist power levels and doses of this radiation that violently destroy cancer cells sensitized with mNPs, but that are evidently safe for cells unsensitized with mNPs.

While melanin, the pigment present in abundance in melanoma cells, plays an important role in skin protection against ultraviolet radiation, it also affects melanoma behavior by adjusting epidermal homeostasis $[27,28]$. Melanoma is, of course, a serious skin cancer, originating from mutated melanocytes, melanin-producing cells [29]. Highly metastatic, it causes about 60,000 deaths per year globally [30]. Very limited progress 
treating melanoma has been achieved with chemotherapy [31], immunotherapy [32], radiotherapy [33], surgery [34,35], or other therapies [36,37]. Melanin synthesis, a multistep and highly regulated route, determines the difference between the function of normal and cancerous cells [38]. Different from healthy melanocytes, in which melanin synthesis is controlled by various factors and plays an important biological role, melanin pigmentation in melanoma cells is dysregulated, which leads to heavy pigmentation of these cells $[39,40]$. Sarna et al. [41] have suggested that the elastic properties of melanoma cells are affected by the melanin presence, and play a key role in melanoma metastasis [38]. Other studies confirm that melanin pigmentation is an important factor in determining the fate of cancer cells [39,42]. Metabolic functions of normal cells are dramatically changed in the cancerous state, and this transformation makes cancer cells strongly dependent on high rates of glucose uptake $[43,44]$.

To achieve rapid cancer cell proliferation in vitro, cell culturing methods commonly use high glucose of Dulbecco's modified Eagle's medium (DMEM, $25 \mathrm{mM}$ or $4500 \mu \mathrm{g} \cdot \mathrm{mL}^{-1}$ ). Normal serum glucose levels in the body are usually constant between 4 and $6 \mathrm{mM}$ $\left(720-1080 \mu \mathrm{g} \cdot \mathrm{mL}^{-1}\right)$. However, the body may experience a drop in glucose level to $2.5 \mathrm{mM}$ $\left(450 \mu \mathrm{g} \cdot \mathrm{mL}^{-1}\right)$, and even further in tissue, in the case of nutrient deficiencies. Accordingly, glucose level reduction has been applied for cancer treatment through different methods such as fasting or modifying (e.g., ketogenic) diet $[45,46]$.

\section{Materials and Methods}

\subsection{Reagents}

Chemicals were purchased from commercial sources with high purity and used as received. Malignant melanoma A375 and HeLa cell lines were obtained from the Shanghai Institute of Cell Biology (Shanghai, China). The cells were cultured in DMEM (Solarbio, Beijing, China) with $10 \%$ fetal bovine serum (Solarbio) and 5\% antibiotics (100 Unit $\mathrm{mL}^{-1}$ penicillin and $100 \mu \mathrm{g} \cdot \mathrm{mL}^{-1}$ streptomycin) from Sigma-Aldrich (St. Louis, MO, USA). The cells were incubated in a cell incubator under $95 \%$ humidity and $5 \% \mathrm{CO}_{2}$ at $37^{\circ} \mathrm{C}$. To seed and harvest the cells, Trypsin-EDTA $(0.25 \%)$ from Sigma was utilized, and Trypan blue $(0.4 \%)$ from Gibco was applied for cell counting purposes.

\subsection{Synthesis of Melanin Nanoparticles, $m N P$}

The synthesis of highly spherical monodispersed mNPs was accomplished using the oxidative polymerization of dopamine hydrochloride in the presence of ethanol and ammonia solution at room temperature. A mixture of aqueous ammonia solution $\left(\mathrm{NH}_{4} \mathrm{OH}\right.$, $0.5 \mathrm{~mL}$ for $320 \mathrm{~nm}$-diameter $\mathrm{mNPs})$, ethanol $(40 \mathrm{~mL})$, and deionized water $(90 \mathrm{~mL})$ was stirred at room temperature for $30 \mathrm{~min}$. This was followed by addition of $0.5 \mathrm{~g}$ of dopamine hydrochloride dissolved in water. A gradual change in color of the solution from light brown to dark brown was observed. The reaction was continued for $24 \mathrm{~h}$, and the formed mNPs were extracted through centrifugation at $7000 \mathrm{rpm}$, and washed three times with deionized water. Different sizes of nominally spherical nanoparticles were obtained by varying the volume of ammonium hydroxide, while following the same protocol.

\subsection{Preparation of Glucose-Coated Melanin Nanoparticles, $m N P @ G$}

As-prepared mNPs $(20 \mathrm{mg})$ were dissolved in tris-buffer $(0.01 \mathrm{M}, \mathrm{pH} 7.5)$ and stirred for $10 \mathrm{~min}$ followed by addition of $0.5 \mathrm{~g}$ acetylglucosamine sugar dissolved in $10 \mathrm{~mL}$ deionized water. The reaction mixture was stirred for $24 \mathrm{~h}$ and then collected through centrifugation. After repeated washing with deionized water, the obtained mNP@G product was redispersed in $1.5 \mathrm{~mL}$ of deionized water for further characterization.

\subsection{Cell Viability Measurements}

Using Cell Counting Kit-8 assay (CCK-8, Sigma-Aldrich, St. Louis, MO, USA), cell viability was determined according to the manufacturer's protocol with some modification, as explained in Supplementary Materials and Figure S1. The CCK-8 colorimetric assay 
involves metabolic bioreduction of WST-8 [2-(2-methoxy-4-nitrophenyl)-3-(4-nitrophenyl)5-(2,4disulfophenyl)-2H-tetrazolium, mono-sodium salt] in the presence of 1-methoxy PMS as an electron mediator, producing a water-soluble orange colored formazan dye. The amount of produced formazan is directly proportional to the number of living cells and can be measured by spectrophotometric method via absorbance of $460 \mathrm{~nm}$. For these measurements, VM-M3, A375, and HeLa cancer cells were seeded, and injected at controlled concentrations into 24 well plates. The cells were incubated overnight in $5 \% \mathrm{CO}_{2}$ atmosphere at $37^{\circ} \mathrm{C}$ to allow adherence to the plate. For comparison, the cells were treated with different concentrations of $\mathrm{mNPs}$ and also $\mathrm{mNP@G}$, and the plates were returned to the incubator for $15 \mathrm{~h}$. Afterwards, $50 \mu \mathrm{L}$ of CCK-8 was added to every well in culture medium, and after incubation for $3 \mathrm{~h}$, the upper orange solution was removed, collected in centrifuge tubes, and centrifuged for $15 \mathrm{~min}$ at 10,000 rpm in order to remove the melanin nanoparticles from the formazan solution. Thereafter, the absorbance of the solution from every tube was measured separately by spectrophotometer (Lambda 950, PerkinElmer, Boston, MA, USA) in the wavelength range of $350-550 \mathrm{~nm}$, and the viability was calculated at the maximum absorption wavelength $(460 \mathrm{~nm})$.

\subsection{Biocompatibility and Cytotoxicity Measurements}

Biocompatibility and cytotoxicity of various concentrations of mNPs and mNP@G from 140 to $2100 \mu \mathrm{g} \cdot \mathrm{mL}^{-1}$ were studied via cell viability and proliferation of the A375 and HeLa cell lines, with the latter also studied in high $\left(4500 \mathrm{mg} \cdot \mathrm{L}^{-1}\right)$ and low glucose (1000 mg $\cdot \mathrm{L}^{-1}$ ) growth media, using CCK-8 assays kits (Sigma-Aldrich, St. Louis, MO, USA). To complete this study, we used UV-Vis spectrophotometry to evaluate cell viability, cell membrane damage and cell toxicity.

\subsection{Theoretical Estimate of the Thermal Effects}

To estimate the photothermal response of the in-blood circulating tumor cells sensitized with mNPs, we modeled the cell as a water droplet with average radius $r_{c} \approx 5 \times 10^{-6} \mathrm{~m}$, immersed in blood serum, which for simplicity is also modeled as water, with thermal conductivity $k_{m}=0.6 \mathrm{~W} \cdot \mathrm{K}^{-1} \cdot \mathrm{m}^{-1}$, specific heat $c_{w}=4186 \mathrm{~J} \cdot \mathrm{kg}^{-1} \cdot \mathrm{K}^{-1}$, and density $\rho_{w}=1000 \mathrm{~kg} \cdot \mathrm{m}^{-3}$. The initial temperature of the cell and the blood is $T_{0}$. The cell is filled with a number $N$ of much smaller, but highly radiation-absorbing $\mathrm{mNPs}$. Each $\mathrm{mNP}$ has radius of $r_{m} \approx 10^{-7} \mathrm{~m}$ and thermal conductivity $k_{m}=0.1 \mathrm{~W} \cdot \mathrm{K}^{-1} \cdot \mathrm{m}^{-1}$. The time evolution of the average temperature change $\Delta T_{c}=T c-T 0$ of a single cell is approximately given by:

$$
\propto \frac{\partial \Delta T_{c}}{\partial t} \approx \varnothing-\beta \Delta T_{\mathcal{C}}
$$

where $\alpha=\frac{4}{3} r_{c} \rho_{w} c_{w}, \beta=4 k_{w} / r_{c}$, and $\varnothing$ is the radiation power density absorbed in all mNPs, given approximately by $\varnothing \approx \varnothing_{\text {inc }} N\left(\frac{r_{m}}{r_{c}}\right)^{2}$, under the assumptions that the mNPs absorb the radiation perfectly and the radius of the laser beam in our experiment is roughly $r_{c}$. The solution to Equation (1) is

$$
\Delta T_{c}=(\varnothing / \beta)\left[1-\exp \left(-\frac{\beta}{\alpha} t\right)\right]
$$

The maximum temperature increase is achieved for $\frac{\beta}{\alpha} t \gg 1$, or for $t \gg \frac{\alpha}{\beta}=\frac{r_{c}^{2} \rho_{w} c_{w}}{3 k_{w}}=t_{c}$, such that $\Delta T_{c \max }=\varnothing / \beta=\varnothing r_{c} / 4 k_{w}$. Choosing a value of $N=1000$, which corresponds to a low $\mathrm{mNP}$ load, and a power density as applied in this work, $\varnothing_{\text {inc }} \approx 10^{9} \mathrm{~W} \cdot \mathrm{m}^{-2}$, we estimate $\varnothing \approx 4 \times 10^{10} \mathrm{~W} \cdot \mathrm{m}^{-2}$. With $\beta=0.5 \times 10^{6} \mathrm{~W} \cdot \mathrm{Km}^{-2}$, Equation (2) gives $\Delta T_{\text {cmax }} \approx 1000 \mathrm{~K}$. This is the order of heating that causes rapid boiling of the cell interior, and can lead to the cell lysis observed in our experiment, as discussed later. The time to achieve such a level of heating is of the order of $t_{\max } \gg t_{c} \approx 10^{-4} \mathrm{~s}$. It is important to note that this power density has no effect on the cells not having mNPs and immersed in water, 
since the penetration length in water at this frequency is very large, $\eta \approx 10 \mathrm{~m}$. Thus, a negligible fraction of the incoming radiation, of order $\varnothing \approx \varnothing_{i n c} \frac{2 r_{c}}{\eta} \approx \varnothing_{i n c} 10^{-6}=10^{3} \mathrm{~W} \cdot \mathrm{m}^{-2}$, is absorbed in a cell, in general agreement with our experiments. It is also in good agreement with laser tweezer experiments [38] in which cells, free of any nanoparticles, were subjected to NIR radiation with power density $\varnothing_{i n c}=3.8 \times 10^{10} \mathrm{~W} \cdot \mathrm{m}^{-2}$ for $15 \mathrm{~min}$. It was shown in that experiment that this much larger power density and dose as compared with our experiment caused no delay in cell growth or increased mortality. Our simple estimate thus well explains the basic physics of our experiments with radiation.

\section{Results and Discussion}

\subsection{Characterization of $m N P @ G$}

Figure 1 shows SEM images of as-prepared mNPs of different sizes (between 100 and $300 \mathrm{~nm}, \pm 17 \mathrm{~nm}$ ), obtained by variation of the $\mathrm{NH}_{4} \mathrm{OH}$ solution volume. As seen in Figure 1f, the $\mathrm{mNP}$ diameter is a linear function of the solution $\mathrm{pH}$. As shown in Figure 2, a slight increase in size, e.g., from $145 \mathrm{~nm}$ for $\mathrm{mNPs}$ to $166 \mathrm{~nm}$ for $\mathrm{mNPs} @ \mathrm{G}$ (i.e., with $\sim 10 \mathrm{~nm}$ average glucose coating thickness), was observed after surface functionalization with amino sugar, indicating surface coverage by the glucose. Figure $2 \mathrm{c}$ shows the optical absorption of aqueous solutions containing mNPs and MNP@G at the same concentration $\left(0.1 \mathrm{~g} \cdot \mathrm{L}^{-1}\right)$, recorded using UV-Vis-NIR spectroscopy. The spectra are similar, with the higher absorption of mNP@G in the visible range due to glucose coating. Surface functional groups of nanomaterials intended for biomedical application are crucial for their hydrophilicity and dispersibility in water and various biofluids. Thus, the chemical groups of melanin and the corresponding sugar-coated analog samples were determined using FTIR spectroscopy (Figure 2d). The intense $\mathrm{C}=\mathrm{O}$ stretches from aromatic rings and/or carboxyl groups of the mNPs that almost suppressed other peaks can be observed at $1685 \mathrm{~cm}^{-1}$. The broad $\mathrm{OH}$ stretch of glucosamine alone can be visibly seen between $2700-3500 \mathrm{~cm}^{-1}$. The FTIR of the mNPs@G displayed an overlap of $\mathrm{NH}_{2} / \mathrm{OH}$ stretching around $3200-3500 \mathrm{~cm}^{-1}$. The $\mathrm{C}-\mathrm{O}$ and $\mathrm{C}-\mathrm{C}$ vibrational band arising from Schiff's base reaction can be seen at $1097 \mathrm{~cm}^{-1}$ and $1298 \mathrm{~cm}^{-1}$ in the $\mathrm{mNPs} @ \mathrm{G}$ (Figure 2d), indicating successful functionalization.
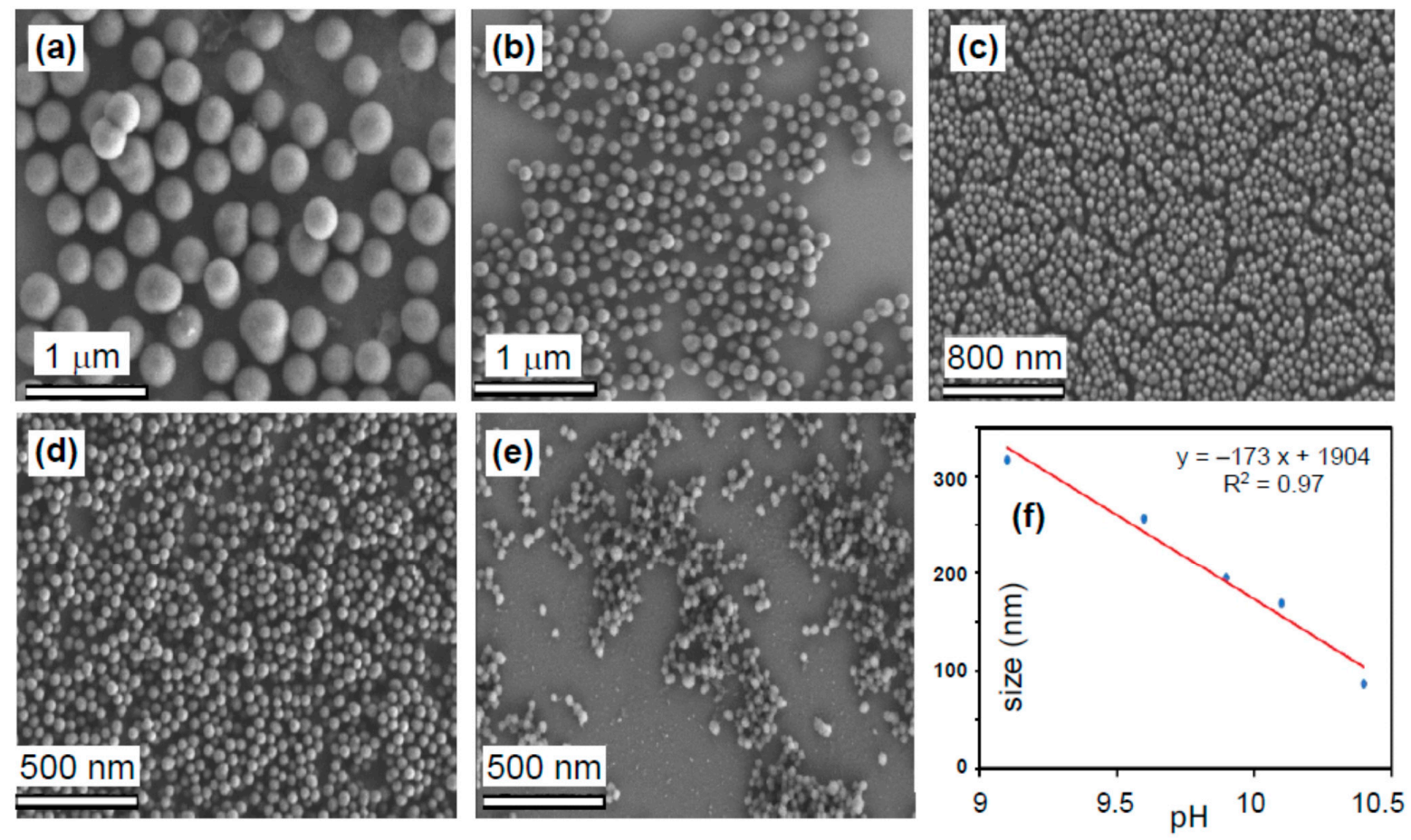

Figure 1. SEM images of mNPs in different volumes of $\mathrm{NH}_{4} \mathrm{OH}$ : (a) 0.5 (b) 1.0, (c) 1.5, (d) 2.0, and (e) $2.5 \mathrm{~mL}$. (f) Plot of mNP diameter vs. $\mathrm{pH}$ of $\mathrm{NH}_{4} \mathrm{OH}$ solution. 

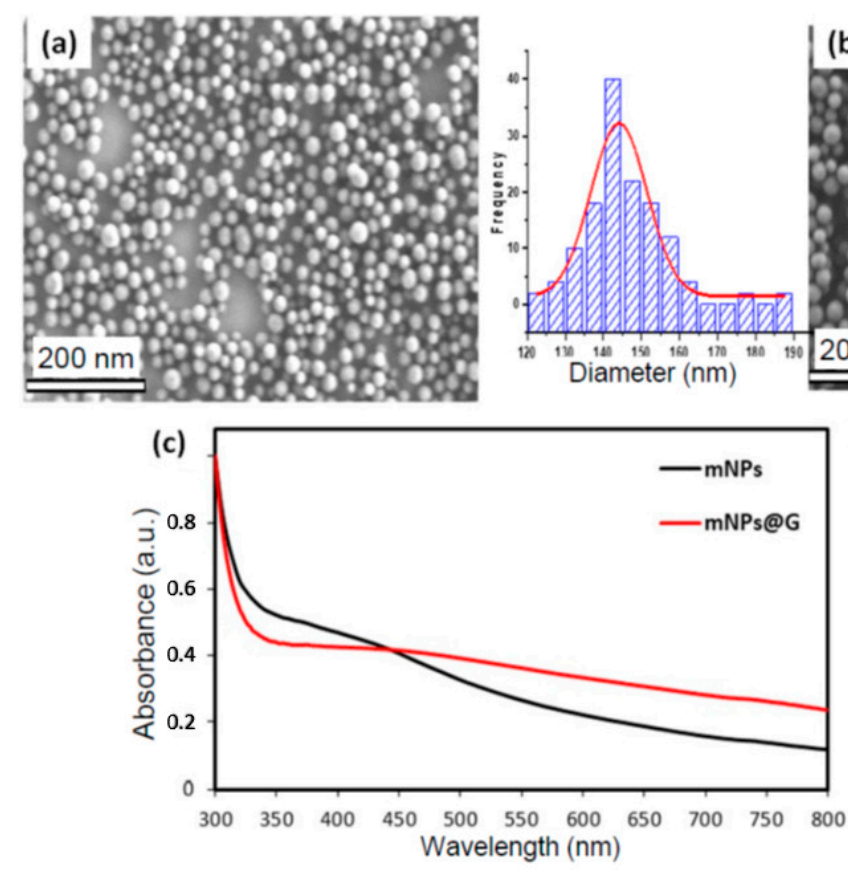
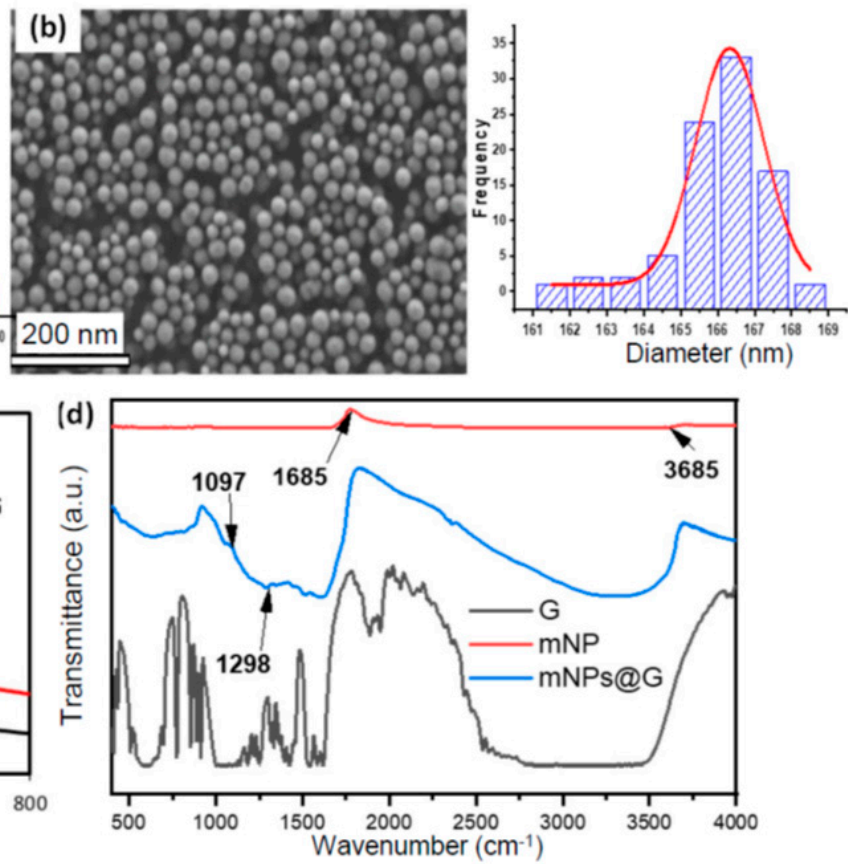

Figure 2. (a,b) SEM images and the corresponding size distribution histograms for mNP and mNP@G, respectively; (c) UV-Vis absorption of mNP (black) and mNP@G (red line). (d) FTIR spectra of terminal amino glucose (black line), mNP (red line), and mNPs@G (blue line).

\subsection{Cell Viability after $m N P$ and $m N P @ G$ Uptake}

The main observations in this part of our study are: (1) non-cancerous or nonmalignant cancer cells studied here do not ingest mNPs, (2) the studied malignant cancer cells massively absorb mNPs (macrophagic/phagocytic character), (3) this uptake is much stronger for the glucose-coated mNPs, (4) cell viability diminishes with increasing number of absorbed mNPs, and (5) lower glucose content in the cell nutrition dramatically reduces cell viability.

Figure 3 exemplifies the observations (1) and (2). It shows optical microscope images of a VM-M3 cell (top panels) and a VM-NM1 cell (bottom panels), both exposed to approximately the same amount of mNPs ( $26 \mathrm{~h}$ incubation time), and taken with focal planes at increasing depth into a cell (from left to right). This allows one to view cell interiors, and the nominal location of the absorbed nanoparticles. Clearly, the malignant VM-M3 cell contains mNPs throughout its interior. In contrast, the non-malignant VM-NM1 cell has no $\mathrm{mNPs}$ in its interior; these agglomerated in large clumps outside the cell. This confirms that only the malignant cells have phagocytic behavior. Similarly, in several similar tests (not shown here), we observed that healthy, non-cancerous cells also do not ingest mNPs. 

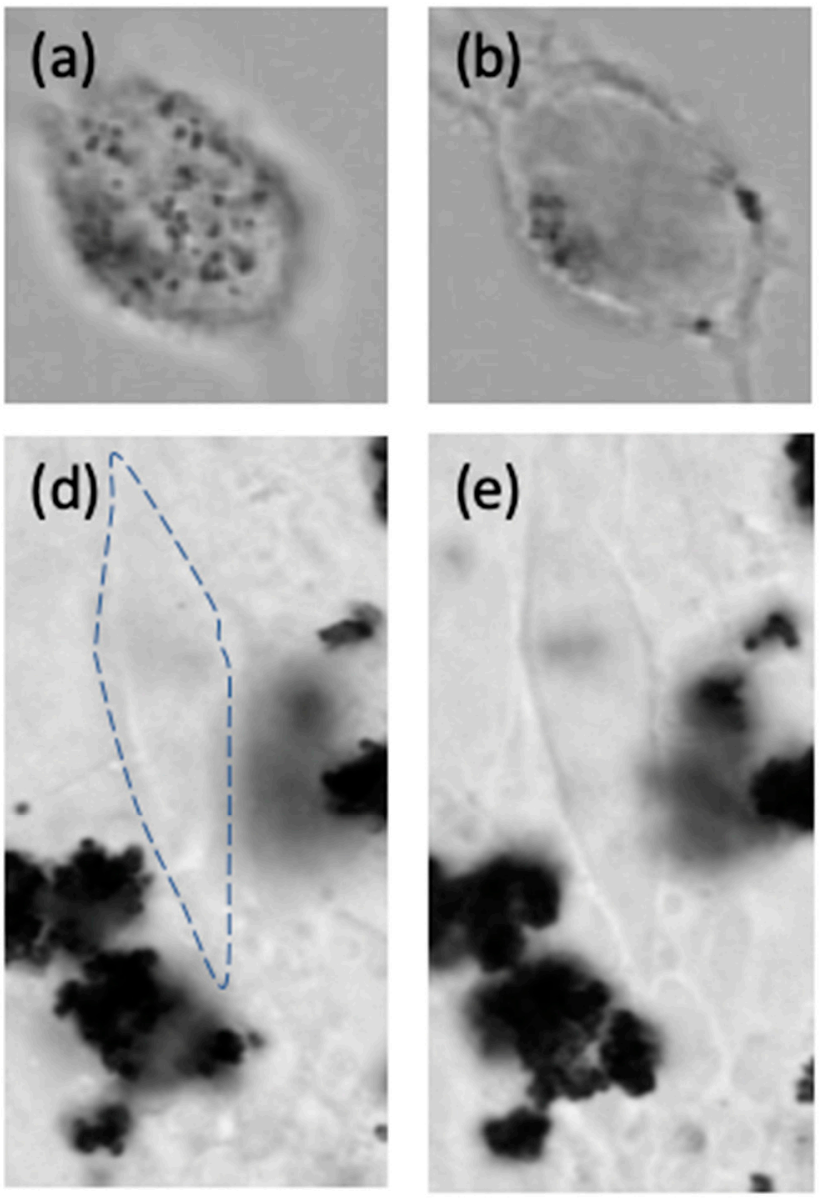
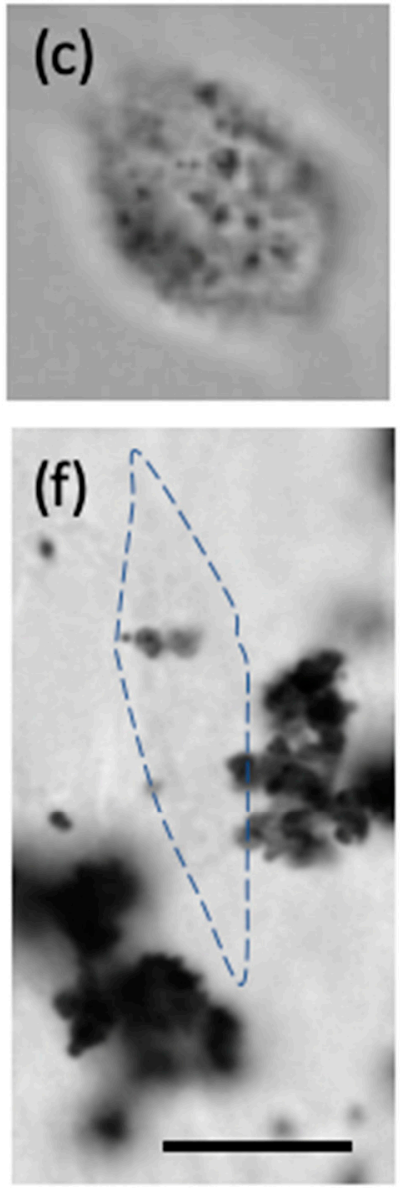

Figure 3. Optical microscope images of a VM-M3 cell (a-c) and a VM-NM1 cell (d-f), taken at changing focal plane depths: near the top cell surface $(\mathbf{a}, \mathbf{d})$, middle of the cell $(\mathbf{b}, \mathbf{e})$, and near the bottom cell surface $(\mathbf{c}, \mathbf{f})$. Both cells are shown after $26 \mathrm{~h}$ incubation with mNPs. The common scale bar is $10 \mathrm{~m}$. The dashed line in $(\mathbf{d}, \mathbf{f})$ outlines the cell shape as in (e).

Figure 4 exemplifies observations (3), (4) and (5) listed above. Figure 5a shows A375 cell viability versus concentration of mNP@G for two different glucose concentrations in the growth medium, and Figure $3 \mathrm{~b}$ shows similar effects for the HeLa cells that normally, in contrast to the melanoma cells, contain no melanin nanoparticles. For more details, see the Supplementary Materials. Note that a much longer incubation time (62 h) was used for higher concentrations of glucose in the growth medium compared to lower concentrations. This is simply because cells absorb the molecular glucose from the growth medium before they begin absorbing the much larger, glucose-coated nanoparticles. Thus, the incubation time approximately scales with the glucose concentration in the growth medium. The reason for higher cell viability at the same mNP concentration in high glucose concentration is not entirely clear. However, it is consistent with the Warburg effect according to which cancer cells benefit from increased amounts of glucose in the medium. One mechanism could be strengthening the cancer cell metabolism, which reduces the cytotoxic effects of $\mathrm{mNPs}$. These suggest that a low glucose diet (e.g., ketogenic) for cancer therapies based on nanoparticles could be beneficial. Our results are in broad agreement with other reports on a variety of cancer cells [47-50]. 

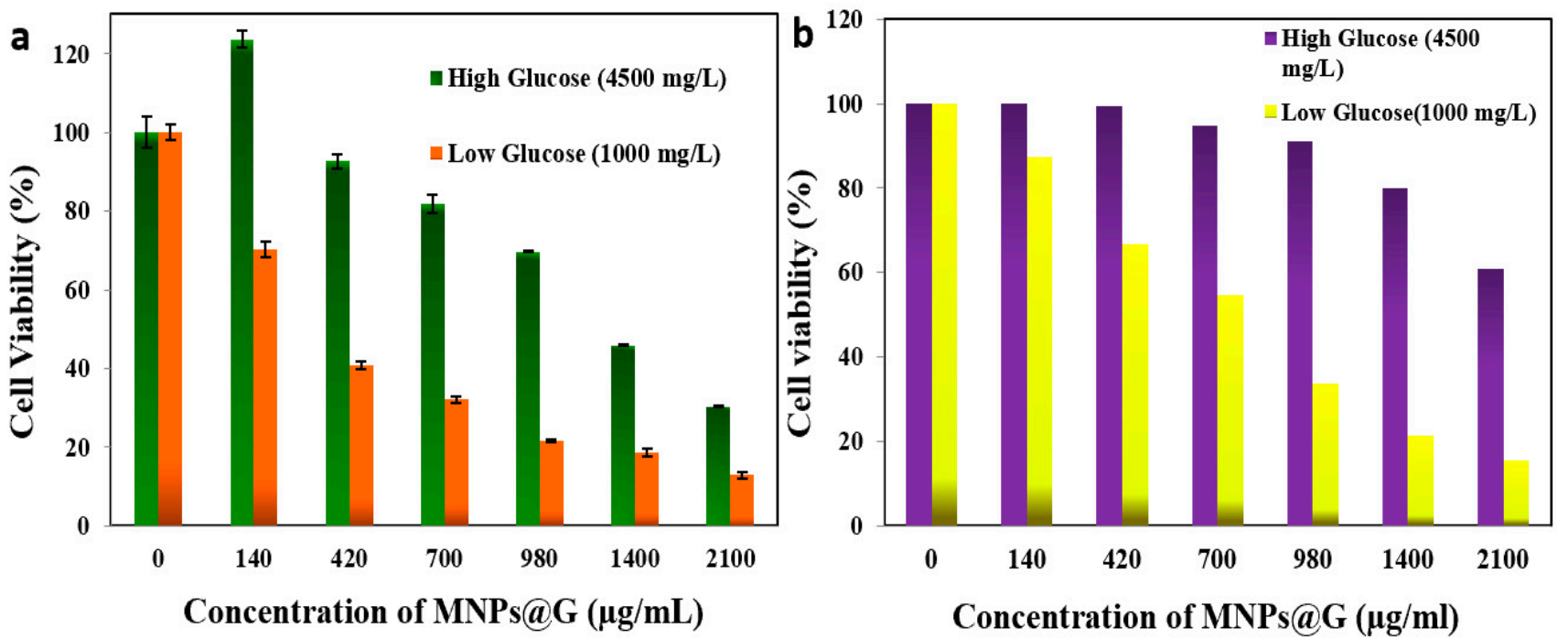

Figure 4. (a) A375 melanoma and (b) HeLa cell viability according to CCK-8 assay as a function of mNP@G concentration after $62 \mathrm{~h}$ incubation in high glucose growth medium $\left(4500 \mathrm{mg} \cdot \mathrm{L}^{-1}\right)$ and $15 \mathrm{~h}$ incubation in low glucose growth medium $\left(1000 \mathrm{mg} \cdot \mathrm{L}^{-1}\right)$.
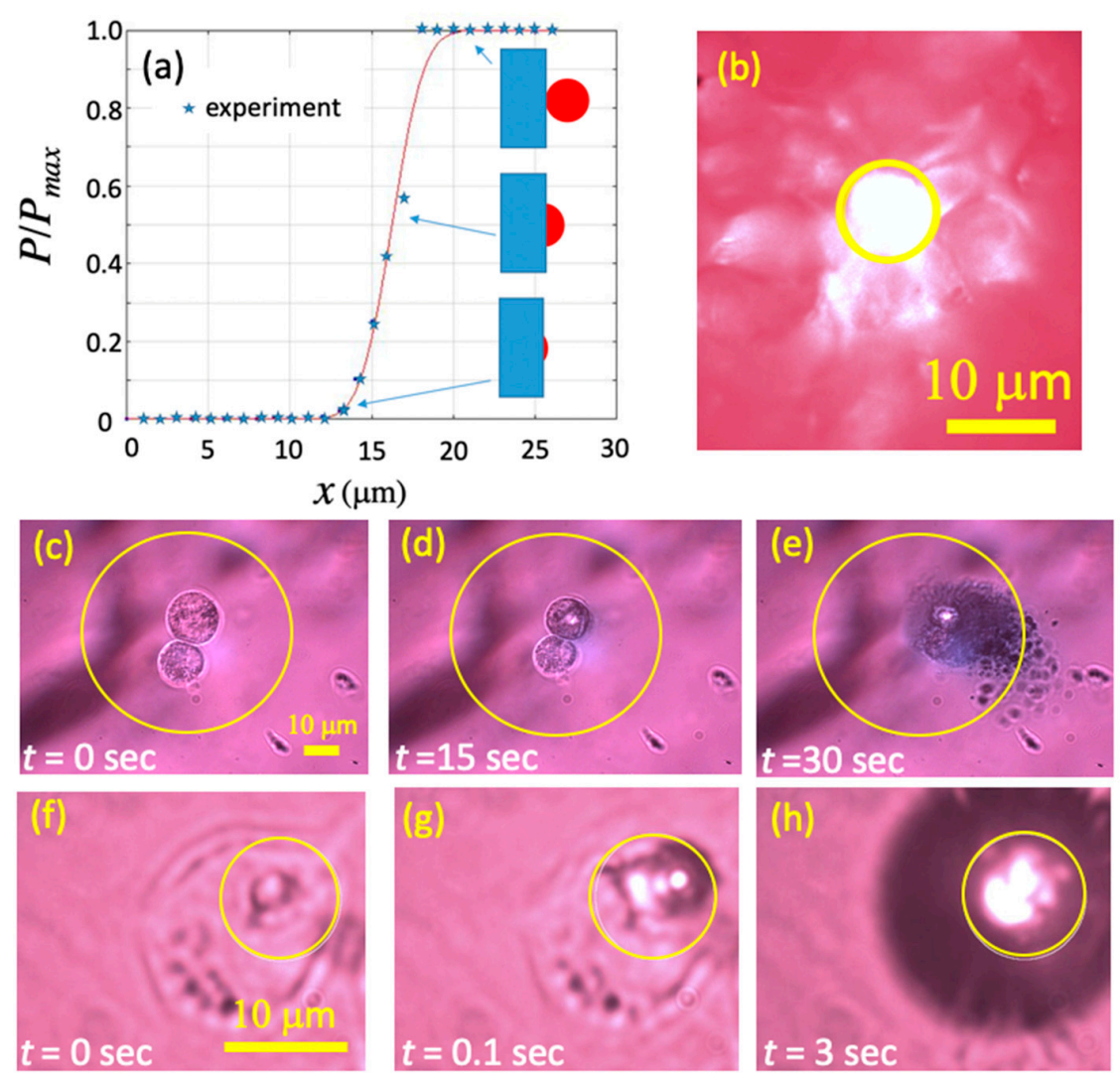

Figure 5. (a) Optical power (scaled to its maximum) versus position, measured using the blade edge shading effect. The insets sketch approximate blade-beam relative locations at selected points. (b) Optical image of the laser spot obtained by using the fluorescent card. (c-e) Images of two VM-M3 cells moderately filled with $\mathrm{mNPs}$, at various exposure times to laser light, at $10 \times$ magnification (light power density $\varnothing_{\mathrm{inc}} \approx 6 \times 10^{7} \mathrm{~W} \cdot \mathrm{m}^{-2}$ ). (f-h) Images of a VM-M3 cell moderately filled with mNPs, at various exposure times to laser radiation, at $100 \times$ magnification (power density $\varnothing_{\text {inc }} \approx 1.4 \times 10^{9} \mathrm{~W} \cdot \mathrm{m}^{-2}$ ). Yellow circles mark approximate beam diameter, which changes with magnification. 
The mechanism of the mNPs cytotoxicity is unclear at this point. It might be due to the nanoscopic size of the mNPs, which dramatically increases surface area for molecular chemical reactions with the cell interior components. Note that the melanin produced by melanocytes occurs in the form of microcrystals (average diameter $D$ ), much larger than mNPs in the current work (each with average diameter $d$ ) and thus, for the same melanin volume, have much smaller surface area (approximately $d / D$ ). If melanin had some finite surface-based cytotoxic effect, it would be expected to be enhanced with mNPs. Biologically active melanin has indeed been reported to be cytotoxic [51].

\subsection{Cell Viability after Exposure to Radiation}

Our custom-designed laser system employed a $532 \mathrm{~nm}$ wavelength diode pumped solid state laser, coupled to the input port of a fluorescent microscope. The beam was aligned and centered to the back aperture of an objective, and reflected light was filtered with a dichroic mirror. The sample was viewed and data recorded via Thorcam. The laser spot size on the sample was determined by the knife edge technique. As the blade moves across the laser spot, the measured laser light power $P$ varies from zero to $P_{\max }$, and the shortest distance between these corresponding edge locations is recorded. This measurement is averaged over different heights and the diameter of the spot is then extrapolated by fitting a hyperbolic equation. Figure 5a shows a scaled plot of $P$ vs. position $x$ (with arbitrary origin) and the insets sketch approximate blade-beam locations at selected points. Figure $5 \mathrm{~b}$ shows an optical image of the laser spot (with diameter $D \approx 7 \mu \mathrm{m}$, marked by a yellow circle) on a fluorescent card, for a chosen magnification setup on the microscope.

Figure 5c-e shows images of two VM-M3 cells moderately filled with mNPs, at various exposure times to laser radiation, and at an identical magnification setup. Due to filtering, the laser spot is invisible, so its outline is marked with a $\sim 50 \mu \mathrm{m}$ diameter yellow circle. The power density is moderate, $\varnothing_{\text {inc }} \approx 6 \times 10^{7} \mathrm{~W} \cdot \mathrm{m}^{-2}$, but enough to initiate visible cell damage after $15 \mathrm{~s}$ of exposure, and catastrophic cell damage (explosion) after $30 \mathrm{~s}$. To better match the size of the laser spot to cell dimensions, we have changed the magnification setup and laser power. The effect of that scenario on a (different) VM-M3 cell, again moderately filled with mNPs, is shown in Figure $5 \mathrm{f}-\mathrm{h}$. This time, the laser spot (also marked with a yellow circle) has diameter $\sim 7 \mu \mathrm{m}$, and the corresponding power density is much larger, $\varnothing_{\text {inc }} \approx 1.4 \times 10^{9} \mathrm{~W} \cdot \mathrm{m}^{-2}$. The figure shows that the damage is now very localized, clearly starting at the clusters of mNPs, with damage obvious already after $0.1 \mathrm{~s}$ exposure, and complete catastrophic cell damage after only $3 \mathrm{~s}$. The white spots visible inside the high laser intensity regions are due to photoluminescence of highly excited mNPs. The results in this figure confirm a well-known fact that visible light can inflict damage to cells, including catastrophic damage. Such a process would be of little therapeutic use if it was not selective.

We found that the level of radiation capable of catastrophically destroying mNPfilled VM-M3 cells, like in Figure 5, is safe for VM-M3 cells not sensitized with mNPs. In this experiment, $\mathrm{mNP}$-unfilled cells were grown on a microscopic slide, marked with a $1 \mathrm{~mm} \times 1 \mathrm{~mm}$ grid to track cells throughout the experiment. The optical microscope image of the slide, shown Figure 6a, was taken $24 \mathrm{~h}$ after exposure to laser light of cells in the box numbered 5 (solid-red outline). The cells experienced the same power density (and approximately the same exposure time) as the cell shown in Figure 5h. The cells in the bracketed boxes 1-4 were not exposed to the laser. During the $24 \mathrm{~h}$, the cells were incubated, and at the end, the Live/Dead Cell Staining Kit II (PromoKine) assay was applied, to visualize cell viability. Figure 6a shows that the cells take up the Calcein-AM dye, resulting in green fluorescence, and are not permeable to the EthD-II dye, which would result in red fluorescence. Thus, all cells remain alive. 


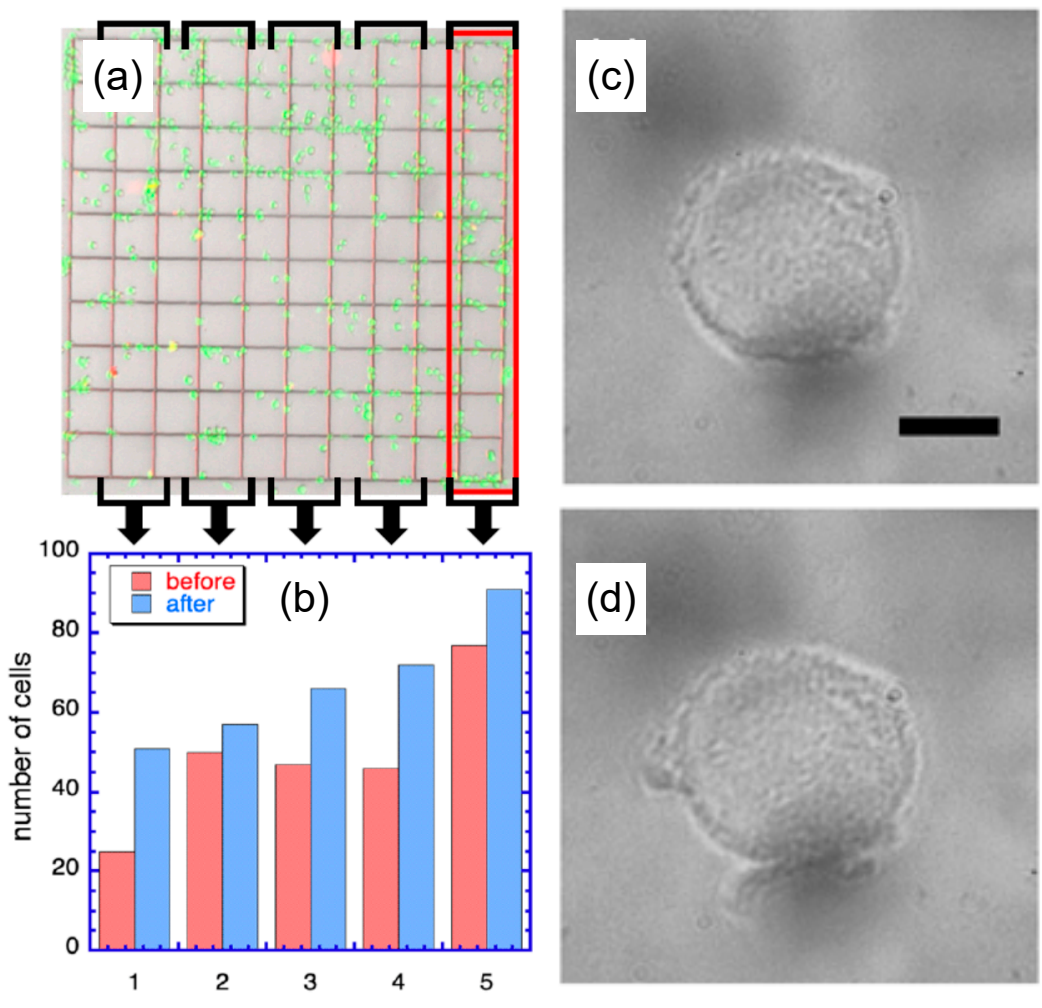

Figure 6. Effect of laser light on VM-M3 cells unfilled with mNPs. (a) Live/dead cell staining test: all cells luminesce green and none red, indicating all are alive and growing. Only cells within the red-outlined, bracketed box have been exposed to the laser. (b) Bar diagram of cell counts in boxes $1-5$, with red $=$ before and blue $=24 \mathrm{~h}$ after laser exposure of cells in box 5, all in growth medium. (c) An mNP-free, single VM-M3 cell before and (d) after laser exposure as described in the text. Scale bar $10 \mu \mathrm{m}$.

Figure $6 \mathrm{~b}$ shows a population bar diagram in the corresponding 5 boxes, where each box is represented by two bars: red bars before and blue bars after laser illumination of box 5 . The red bars show that the initial cell distribution was roughly uniform in boxes $2-4$ (with an average cell number per box $\sim 47$ ), box 1 had $\sim 25$, and box $5, \sim 75$ cells. After $24 \mathrm{~h}$, the number of alive cells increased in all boxes (growing cells), including laser-exposed box 5 . It is also clear that the overall distribution of cells on the grid changed, with the number of cells per box gradually increasing, e.g., to $\sim 50$ in box 1 and to $\sim 90$ in box 5 . This effect likely results from a combination of natural cell population growth and temperature rise from laser heating of box 5 , and the heat transfer away from this box. The resulting temperature profile during illumination would then be asymmetric, with a gradual temperature drop towards box 1, with cell growth reflecting this profile. Recorded movies of the details of these mNP-filled cells explosively damaged, as well as of the unfilled cells remaining unaffected, can be found in the Supplementary Materials. To demonstrate the lack of visible damage at the microscopic level, we show optical images of a single, mNP-unfilled MV-M3 cell before (panel c), and after (panel d) laser illumination, at the same level as applied in panel (a). As expected, the radiation produces no visible change in the cell.

The main results in this part of our study are: (a) compared with the cytotoxicity of nanoparticles alone, laser-induced cell death requires much lower density of absorbed nanoparticles, (b) all cells filled with absorbing nanoparticles (e.g., mNPs) are destroyed by radiation, at sufficient power level-this would include melanoma cells, naturally filled with melanin microcrystals, and (c) there is a laser power range at which the nanoparticlefilled cancer cells are violently destroyed, while the nanoparticle-free cells remain alive. This is a key finding of this work, since the nanoparticle-filled cells do not have to be 
so violently destroyed to be killed, and so the applied laser power level can be strongly reduced. This lower power level obviously will not damage the nanoparticle-free cells.

Our nanoparticle-based strategy could be used as a basis for or part of a cancer therapy (e.g., optochemotherapy), for example to target circulating tumor cells which mediate metastasis. In such a therapy, an intravenous injection could accomplish the first stage of the mNPs feeding into CTCs. This step could be enhanced by additional bio-engineered CTC targeting schemes. Next, in one possible scenario, one could expose the blood of a cancer patient to light externally, in a dialysis-like scheme. This would lead to a dramatic reduction in the CTC population, thus significantly reducing the effects of metastasis.

\section{Conclusions}

We have observed massive cellular uptake of melanin nanoparticles by the studied metastatic cancer cells (macrophagic/phagocytic character) which, at sufficiently high density, causes a cytotoxic effect. This effect is further enhanced by coating the nanoparticles with glucose, and simultaneous reduction of the glucose level in the growth medium. We also demonstrated that nonionizing visible light at moderate power levels kills these metastatic cancer cells, at much lower mNP uptake levels. Cell death occurs in this case via hyperthermia-induced lysis, and we found this process to be target-selective, as nonmalignant cancer cells studied here that could not ingest the melanin nanoparticles remain unaffected, despite receiving identical optical energy levels and doses. This technique could enhance a future cancer metastasis preventing therapy.

Supplementary Materials: The following are available online at https:/ / www.mdpi.com/article/10 .3390 / pharmaceutics13070965/s1. Scheme S1: WST-8 based cytotoxicity assay mechanism, Table S1: Zeta potential $\zeta$ of cancer cells and nanoparticles in buffer, Video S1: video corresponding to Figure 6, Video S2: recorded video of un-sensitized VM-M3 cells exposed to laser treatment (not being apparently damaged), Video S3: recorded video of sensitized (melanin-filled) VM-M3 cells exposed to laser treatment under identical conditions as Video S2 (being damaged).

Author Contributions: Conceptualization, K.K., M.G., M.J.N. and T.N.S.; methodology, K.K., M.G., M.J.N., T.N.S., A.M., V.R.G. and R.M.M.; validation, K.K., M.G. and M.J.N.; formal analysis, V.R.G., R.M.M., N.A., P.M. and N.N.; resources, K.K., M.G., M.J.N., T.N.S. and E.M.A.; data curation, V.R.G., R.M.M.; writing—original draft preparation, V.R.G., R.M.M., K.K. and N.N.; writing-review and editing, K.K., M.G., M.J.N. and T.N.S.; visualization, V.R.G., R.M.M., N.N. and E.M.A.; supervision, K.K., M.J.N., M.G. and G.Z.; project administration, K.K., M.J.N., M.G., G.Z. and E.M.A.; funding acquisition, K.K., M.G., M.J.N., G.Z. and E.M.A. All authors have read and agreed to the published version of the manuscript.

Funding: This research was funded by the US National Science Foundation, grant number PHY1748906, the Guangdong Innovative and Entrepreneurial Team Program, grant number 2016ZT06C517, and the Science and Technology Program of Guangzhou, grant number 2019050001.

Institutional Review Board Statement: Not applicable.

Informed Consent Statement: Not applicable.

Data Availability Statement: The data presented in this study are available on request from the corresponding author.

Conflicts of Interest: The authors declare no conflict of interest.

\section{References}

1. Serpooshan, V.; Quinn, T.M.; Muja, N.; Nazhat, S.N. Hydraulic permeability of multilayered collagen gel scaffolds under plastic compression-induced unidirectional fluid flow. Acta Biomater. 2013, 9, 4673-4680. [CrossRef]

2. Shi, J.; Kantoff, P.W.; Wooster, R.; Farokhzad, O.C. Cancer nanomedicine: Progress, challenges and opportunities. Nat. Rev. Cancer 2017, 17, 20-37. [CrossRef]

3. Rogach, A.L.; Ogris, M. Near-infrared-emitting semiconductor quantum dots for tumor imaging and targeting. Curr. Opin. Mol. Ther. 2010, 12, 331-339. 
4. De La Isla, A.; Brostow, W.; Bujard, B.; Estevez, M.; Rodriguez, J.R.; Vargas, S.; Castaño, V.M. Nanohybrid scratch resistant coatings for teeth and bone viscoelasticity manifested in tribology. Mater. Res. Innov. 2003, 7, 110-114. [CrossRef]

5. Versiani, A.F.; Astigarraga, R.G.; Rocha, E.S.O.; Barboza, A.P.M.; Kroon, E.G.; Rachid, M.A.; Souza, D.G.; Ladeira, L.O.; Barbosa-Stancioli, E.F.; Jorio, A.; et al. Multi-walled carbon nanotubes functionalized with recombinant Dengue virus 3 envelope proteins induce significant and specific immune responses in mice. J. Nanobiotechnol. 2017, 15, 26. [CrossRef]

6. Chatterjee, D.K.; Diagaradjane, P.; Krishnan, S. Nanoparticle-mediated hyperthermia in cancer therapy. Ther. Deliv. 2011, 2, 1001-1014. [CrossRef]

7. Edelstein, R.L.; Tamanaha, C.R.; Sheehan, P.E.; Miller, M.M.; Baselt, D.R.; Whitman, L.J.; Colton, R.J. The BARC biosensor applied to the detection of biological warfare agents. Biosens. Bioelectron. 2000, 14, 805-813. [CrossRef]

8. Cai, D.; Ren, L.; Zhao, H.; Xu, C.; Zhang, L.; Yu, Y.; Wang, H.; Lan, Y.; Roberts, M.F.; Chuang, J.H.; et al. A molecular-imprint nanosensor for ultrasensitive detection of proteins. Nat. Nanotechnol. 2010, 5, 597-601. [CrossRef]

9. Lai, S.K.; Hida, K.; Man, S.T.; Chen, C.; Machamer, C.; Schroer, T.A.; Hanes, J. Privileged delivery of polymer nanoparticles to the perinuclear region of live cells via a non-clathrin, non-degradative pathway. Biomaterials 2007, 28, 2876-2884. [CrossRef]

10. Mahmoudi, M.; Meng, J.; Xue, X.; Liang, X.J.; Rahman, M.; Pfeiffer, C.; Hartmann, R.; Gil, P.R.; Pelaz, B.; Parak, W.J.; et al. Interaction of stable colloidal nanoparticles with cellular membranes. Biotechnol. Adv. 2014, 32, 679-692. [CrossRef] [PubMed]

11. Chou, L.Y.T.; Ming, K.; Chan, W.C.W. Strategies for the intracellular delivery of nanoparticles. Chem. Soc. Rev. 2011, 40, $233-245$. [CrossRef]

12. Nel, A.E.; Mädler, L.; Velegol, D.; Xia, T.; Hoek, E.M.V.; Somasundaran, P.; Klaessig, F.; Castranova, V.; Thompson, M. Understanding biophysicochemical interactions at the nano-bio interface. Nat. Mater. 2009, 8, 543-557. [CrossRef]

13. Hunter, R.J. Zeta Potential in Colloid Science, 1st ed.; Academic Press: San Diego, CA, USA, 1981; ISBN 9780123619617.

14. Zhang, Y.; Yang, M.; Portney, N.G.; Cui, D.; Budak, G.; Ozbay, E.; Ozkan, M.; Ozkan, C.S. Zeta potential: A surface electrical characteristic to probe the interaction of nanoparticles with normal and cancer human breast epithelial cells. Biomed. Microdevices 2008, 10, 321-328. [CrossRef] [PubMed]

15. Altankov, G.; Richau, K.; Groth, T. The role of surface zeta potential and substratum chemistry for regulation of dermal fibroblasts interaction. Mater. Werkst. 2003, 34, 1120-1128. [CrossRef]

16. Moan, J.; Peak, M.J. Effects of UV radiation on cells. J. Photochem. Photobiol. B Biol. 1989, 4, 21-34. [CrossRef]

17. Baskar, R.; Lee, K.A.; Yeo, R.; Yeoh, K.-W. Cancer and radiation therapy: Current advances and future directions. Int. J. Med. Sci. 2012, 9, 193-199. [CrossRef]

18. Pilát, Z.; Jonáš, A.; Ježek, J.; Zemánek, P. Effects of infrared optical trapping on Saccharomyces cerevisiae in a microfluidic system. Sensors 2017, 17, 2640. [CrossRef]

19. Rothman, L.S.; Gordon, I.E.; Babikov, Y.; Barbe, A.; Chris Benner, D.; Bernath, P.F.; Birk, M.; Bizzocchi, L.; Boudon, V.; Brown, L.R.; et al. The HITRAN2012 molecular spectroscopic database. J. Quant. Spectrosc. Radiat. Transf. 2013, 130, 4-50. [CrossRef]

20. Gabriele, V.R.; Shvonski, A.; Hoffman, C.S.; Giersig, M.; Herczynski, A.; Naughton, M.J.; Kempa, K. Towards spectrally selective catastrophic response. Phys. Rev. E 2020, 101, 62415. [CrossRef]

21. Gamage, S.; Howard, M.; Makita, H.; Cross, B.; Hastings, G.; Luo, M.; Abate, Y. Probing structural changes in single enveloped virus particles using nano-infrared spectroscopic imaging. PLoS ONE 2018, 13, e0199112. [CrossRef]

22. Lee, S.Y.; Yoon, K.A.; Jang, S.H.; Ganbold, E.O.; Uuriintuya, D.; Shin, S.M.; Ryu, P.D.; Joo, S.W. Infrared spectroscopy characterization of normal and lung cancer cells originated from epithelium. J. Vet. Sci. 2009, 10, 299-304. [CrossRef] [PubMed]

23. Galanzha, E.I.; Shashkov, E.V.; Spring, P.M.; Suen, J.Y.; Zharov, V.P. In vivo, noninvasive, label-free detection and eradication of circulating metastatic melanoma cells using two-color photoacoustic flow cytometry with a diode laser. Cancer Res. 2009, 69, 7926-7934. [CrossRef]

24. Luo, X.; Mitra, D.; Sullivan, R.J.; Wittner, B.S.; Kimura, A.M.; Pan, S.; Hoang, M.P.; Brannigan, B.W.; Lawrence, D.P.; Flaherty, K.T.; et al. Isolation and molecular characterization of circulating melanoma cells. Cell Rep. 2014, 7, 645-653. [CrossRef]

25. Vasefi, F.; MacKinnon, N.; Saager, R.; Kelly, K.M.; Maly, T.; Booth, N.; Durkin, A.J.; Farkas, D.L. Separating melanin from hemodynamics in nevi using multimode hyperspectral dermoscopy and spatial frequency domain spectroscopy. J. Biomed. Opt. 2016, 21, 114001. [CrossRef] [PubMed]

26. Jiang, Q.; Luo, Z.; Men, Y.; Yang, P.; Peng, H.; Guo, R.; Tian, Y.; Pang, Z.; Yang, W. Red blood cell membrane-camouflaged melanin nanoparticles for enhanced photothermal therapy. Biomaterials 2017, 143, 29-45. [CrossRef]

27. Slominski, A.; Kim, T.-K.; Brożyna, A.A.; Janjetovic, Z.; Brooks, D.L.P.; Schwab, L.P.; Skobowiat, C.; Jóźwicki, W.; Seagroves, T.N. The role of melanogenesis in regulation of melanoma behavior: Melanogenesis leads to stimulation of HIF- $1 \alpha$ expression and HIF-dependent attendant pathways. Arch. Biochem. Biophys. 2014, 563, 79-93. [CrossRef]

28. Slominski, A.; Tobin, D.J.; Shibahara, S.; Wortsman, J. Melanin pigmentation in mammalian skin and its hormonal regulation. Physiol. Rev. 2004, 84, 1155-1228. [CrossRef]

29. Zhang, W.; Tang, B.; Huang, Q.; Hua, Z. Galangin inhibits tumor growth and metastasis of B16F10 melanoma. J. Cell. Biochem. 2013, 114, 152-161. [CrossRef]

30. American Society of Clinical Oncology, cancer.net. 2020. Available online: https://www.cancer.net/cancer-types / melanoma/ statistics (accessed on 10 March 2021). 
31. Suzuki, H.; Sasaki, E.; Motai, R.; Goto, S.; Nishikawa, D.; Beppu, S.; Terada, H.; Sawabe, M.; Hanai, N. Safety and efficacy of salvage neck dissection following carbon-ion radiotherapy with chemotherapy for a Patient with mucosal malignant melanoma of head and neck. Diagnostics 2020, 10, 82. [CrossRef]

32. Cabrita, R.; Lauss, M.; Sanna, A.; Donia, M.; Skaarup Larsen, M.; Mitra, S.; Johansson, I.; Phung, B.; Harbst, K.; Vallon-Christersson, J.; et al. Tertiary lymphoid structures improve immunotherapy and survival in melanoma. Nature 2020, 577, 561-565. [CrossRef]

33. Filippi, A.R.; Fava, P.; Badellino, S.; Astrua, C.; Ricardi, U.; Quaglino, P. Radiotherapy and immune checkpoints inhibitors for advanced melanoma. Radiother. Oncol. 2016, 120,1-12. [CrossRef]

34. Wang, J.-J.; Li, Z.-F.; Li, X.-J.; Han, Z.; Zhang, L.; Liu, Z.-J. Effects of microRNA-136 on melanoma cell proliferation, apoptosis, and epithelial-mesenchymal transition by targetting PMEL through the Wnt signaling pathway. Biosci. Rep. 2017, 37. [CrossRef]

35. Enomoto, L.M.; Levine, E.A.; Shen, P.; Votanopoulos, K.I. Role of surgery for metastatic melanoma. Surg. Clin. N. Am. 2020, 100, 127-139. [CrossRef]

36. Hocker, T.L.; Singh, M.K.; Tsao, H. Melanoma genetics and therapeutic approaches in the 21st century: Moving from the benchside to the bedside. J. Investig. Dermatol. 2008, 128, 2575-2595. [CrossRef]

37. Pisano, M.; Pagnan, G.; Loi, M.; Mura, M.E.; Tilocca, M.G.; Palmieri, G.; Fabbri, D.; Dettori, M.A.; Delogu, G.; Ponzoni, M.; et al. Antiproliferative and pro-apoptotic activity of eugenol-related biphenyls on malignant melanoma cells. Mol. Cancer 2007, 6, 8. [CrossRef]

38. Slominski, R.M.; Zmijewski, M.A.; Slominski, A.T. The role of melanin pigment in melanoma. Exp. Dermatol. 2015, 24, 258-259. [CrossRef]

39. Brożyna, A.A.; Jóźwicki, W.; Roszkowski, K.; Filipiak, J.; Slominski, A.T. Melanin content in melanoma metastases affects the outcome of radiotherapy. Oncotarget 2016, 7, 17844-17853. [CrossRef]

40. Lazova, R.; Pawelek, J.M. Why do melanomas get so dark? Exp. Dermatol. 2009, 18, 934-938. [CrossRef]

41. Sarna, M.; Zadlo, A.; Hermanowicz, P.; Madeja, Z.; Burda, K.; Sarna, T. Cell elasticity is an important indicator of the metastatic phenotype of melanoma cells. Exp. Dermatol. 2014, 23, 813-818. [CrossRef]

42. Sarna, M.; Krzykawska-Serda, M.; Jakubowska, M.; Zadlo, A.; Urbanska, K. Melanin presence inhibits melanoma cell spread in mice in a unique mechanical fashion. Sci. Rep. 2019, 9, 9280. [CrossRef]

43. Sandulache, V.C.; Ow, T.J.; Pickering, C.R.; Frederick, M.J.; Zhou, G.; Fokt, I.; Davis-Malesevich, M.; Priebe, W.; Myers, J.N. Glucose, not glutamine, is the dominant energy source required for proliferation and survival of head and neck squamous carcinoma cells. Cancer 2011, 117, 2926-2938. [CrossRef]

44. Han, L.; Ma, Q.; Li, J.; Liu, H.; Li, W.; Ma, G.; Xu, Q.; Zhou, S.; Wu, E. High glucose promotes pancreatic cancer cell proliferation via the induction of EGF expression and transactivation of EGFR. PLoS ONE 2011, 6, e27074. [CrossRef]

45. Lee, C.; Longo, V.D. Fasting vs dietary restriction in cellular protection and cancer treatment: From model organisms to patients. Oncogene 2011, 30, 3305-3316. [CrossRef]

46. De Lorenzo, M.S.; Baljinnyam, E.; Vatner, D.E.; Abarzúa, P.; Vatner, S.F.; Rabson, A.B. Caloric restriction reduces growth of mammary tumors and metastases. Carcinogenesis 2011, 32, 1381-1387. [CrossRef]

47. Da Silva, L.P.; Oliveira, S.; Pirraco, R.P.; Santos, T.C.; Reis, R.L.; Marques, A.P.; Correlo, V.M. Eumelanin-releasing spongy-like hydrogels for skin re-epithelialization purposes. Biomed. Mater. 2017, 12, 25010. [CrossRef]

48. Scognamiglio, F.; Travan, A.; Turco, G.; Borgogna, M.; Marsich, E.; Pasqua, M.; Paoletti, S.; Donati, I. Adhesive coatings based on melanin-like nanoparticles for surgical membranes. Colloids Surf. B Biointerfaces 2017, 155, 553-559. [CrossRef]

49. Perring, J.; Crawshay-Williams, F.; Huang, C.; Townley, H.E. Bio-inspired melanin nanoparticles induce cancer cell death by iron adsorption. J. Mater. Sci. Mater. Med. 2018, 29, 181. [CrossRef]

50. Liopo, A.; Su, R.; Oraevsky, A.A. Melanin nanoparticles as a novel contrast agent for optoacoustic tomography. Photoacoustics 2015, 3, 35-43. [CrossRef]

51. Madhusudhan, D.N.; Mazhari, B.B.Z.; Dastager, S.G.; Agsar, D. Production and cytotoxicity of extracellular insoluble and droplets of soluble melanin by Streptomyces lusitanus DMZ-3. BioMed Res. Int. 2014, 2014, 306895. [CrossRef] [PubMed] 